\title{
Cladodes anatomy of Opuntia (Cactaceae) from the province of Buenos Aires (Argentina)
}

\author{
VANESA G. PERROTTA ${ }^{1}$ and ANA M. ARAMBARRI ${ }^{1, *}$
}

\begin{abstract}
Summary: The aim of this study was to deepen the knowledge of the cladodes anatomy of nine species of Opuntia that grow in the province of Buenos Aires, Argentina. Fresh and herbarium samples were prepared according to usual methods for light microscope. Histochemical techniques were performed to identify starch, mucilage and oxalate salts. The main traits found were: epidermis smooth and uniseriate, covered by a thin cuticle and epicuticular waxes; large (range 36-57 $\mu \mathrm{m}$ length) stomata in low density (range 21-27/ $\mathrm{mm}^{2}$ ), located at level respect to the rest of epidermal cells with a deep substomatal chamber; a multiseriate hypodermis with one crystal layer; the cortex with external chlorenchyma and internal hydrenchyma. The eustele presents different size of vascular bundles; in some species the large ones have a secretory duct adjacent to the phloem. Some species showed wide-band tracheids and a few presented fibres in their vascular bundles. Some characters (presence of fibres and ducts) may be a useful tool for plant identification. However, many open questions remain to be investigated such as the correlation of the environment factors with hypodermis, calcium oxalate crystals, and wide-band tracheids.
\end{abstract}

Key words: Buenos Aires province, Opuntia, segment of stems, tissues.

Resumen: Anatomía de los cladodios de Opuntia (Cactaceae) de la provincia de Buenos Aires (Argentina). El objetivo de este trabajo fue profundizar el conocimiento de la anatomía de los cladodios de nueve especies de Opuntia que crecen en la provincia de Buenos Aires, Argentina. Se hicieron preparaciones con material fresco y ejemplares de herbario siguiendo métodos habituales para microscopía óptica. Se usaron técnicas histoquímicas para identificar almidón, mucílagos y sales de oxalato. Las principales características halladas fueron: epidermis lisa y uniseriada, cutícula delgada y ceras epicuticulares; estomas grandes (entre 36-57 $\mu \mathrm{m}$ long) en baja densidad (entre 21-27/ $\mathrm{mm}^{2}$ ), ubicados a nivel con respecto a las restantes células epidérmicas y con una profunda cámara subestomática; hipodermis multiseriada con capa cristalífera; la corteza con clorénquima externo e hidrénquima interno. La eustela presenta haces vasculares de diferente tamaño, en algunas especies los haces mayores presentan un conducto secretor adyacente al floema. Algunas especies presentaron traqueidas con bandas de engrosamiento secundario y muy pocas tuvieron fibras en sus haces vasculares. La presencia de fibras y conducto adyacente al floema pueden ser caracteres útiles en la identificación de especies. Sin embargo, muchos aspectos requieren mayor investigación en relación con los factores ambientales, tales como la hipodermis, los cristales de oxalato de calcio y las traqueidas con bandas de engrosamiento secundario.

Palabras clave: Opuntia, provincia de Buenos Aires, segmentos del tallo, tejidos.

\section{INTRODUCTION}

The family Cactaceae was assigned to order Caryophyllales, suborder Portulacineae (Ortega-

${ }^{1}$ Docentes-Investigadores del Laboratorio de Morfología Comparada de Espermatófitas (LAMCE), Facultad de Ciencias Agrarias y Forestales, UNLP. Avda. 60 y 119, C.C. 31 (1900) La Plata, Argentina. Telephone 54-0221423-6758, ext. 461

*Author to contact: anaramba@yahoo.com.ar; arambarri@ agro.unlp.edu.ar
Baes et al., 2010). It has ample distribution in arid regions of Mexico, Brazil, Argentina and Bolivia as the principal center of diversity, but also is presents in tropical rainforests and temperate areas (Kiesling, 1975, 1988, 2003; Ortega-Baes et al., 2010). In Argentina, the family is represented by 225 species of which 131 are endemic (Zuloaga et al., 1999). Opuntia Mill. (subfamily Opuntioideae, tribe Opuntieae) contains 191 species (Nattero \& Malerba, 2011), and it has a widespread distribution from northern Patagonia to southern Canada (Kiesling, 1975). In Argentina, are growing 30 
species (Kiesling, 1975, 1999, 2005), and in the province of Buenos Aires, Cabrera \& Fabris (1965) described seven species of Opuntia. Zuloaga et al. (2008) cited seven species. Later, Opuntia bonaerensis was recognized, and Long (2012) described a new species, Opuntia ventanensis.

During the last years, many anatomical studies for the family, subfamilies and genera have been performed (e.g. Conde, 1975; Mauseth \& PlemonsRodríguez, 1998; Loza-Cornejo \& Terrazas, 2003; Arruda et al., 2005; Mauseth, 2005, 2006; Melo-dePinna et al., 2006; Pereira de Arruda \& Melo-dePinna, 2015) introducing novelties, but only a few contains some structural data of Argentinian Opuntia species (Vergez Manghi et al., 2015). Therefore, our objective was to deepen the anatomy knowledge of segment of stems (cladodes) of the species of Opuntia from the province of Buenos Aires.

\section{Materials and Methods}

\section{Plant materials studied}

Accessions from the following herbaria have been studied (listed in the Appendix): BA, BAA, LP, SI (acronyms according to Thiers, http:// sweetgum.nybg.org/ih). In addition, fresh samples were surveyed (included in Appendix). To identified the Opuntia collected, and for nomenclature were consulted the following documents and data base: Flora de la provincia de Buenos Aires (Cabrera \& Fabris, 1965), Flora ilustrada de Entre Ríos (Kiesling, 2005), Instituto de Botánica Darwinion, www.darwin.edu.ar, Long (2012), Font (2014), Realini et al. (2014), and Las Peñas et al. (2017).

Fresh samples of cladodes were preserved in formalin-acetic-alcoholic solution (FAA 70\%) (Johansen, 1940) in the Laboratorio de Morfología Comparada de Espermatófitas (LAMCE). A sample of the collected material was cultivated in greenhouse, Botanical Garden and Arboretum "C. Spegazzini”, Facultad de Ciencias Agrarias y Forestales, Universidad Nacional de La Plata. In Fig. 1 is showed the distribution of the studied material in the Buenos Aires province.

\section{Anatomical and histochemical analyses}

To avoid alterations on fresh samples, they were immediately fixed in FAA solution (Johansen, 1940). Dried small pieces of cladodes were reconstituted by immersion in water and placed in an oven at $30^{\circ} \mathrm{C}$ for $24-72 \mathrm{~h}$, then fixed in FAA. To perform anatomy study a small piece from the middle part of the cladode was used. To study characteristics in surface view transparent material was prepared by the following technique of LAMCE Laboratory: at room temperature, samples of cladodes were submerged in a solution of sodium hydroxide (5\%) add sodium hypochlorite (5\%), ratio 1: 1 for 2-5 days. At completion of the bleaching process, five washed in distilled water were carried out to remove the sodium hydroxide and hypochlorite. Samples were then transferred into a solution of chloral hydrate (5\%) for 24-48 h. To analyze the structure, small pieces of cladodes were sectioned transversally, bleached in sodium hypochlorite $(50 \%)$, washed three times with distilled water, and stained with alcoholic solution of safranin $(80 \%)$. Slides were mounted on glycerin jelly (Johansen, 1940).

In surface view external characteristics of epidermal tissue, and internal traits of hypodermis and subepidermal druses were examined. The quantitative analysis was performed on four areas on both cladode surfaces. The epidermal cells size, anticlinal cell walls width; stomata guard cells length and width, and the diameter of subepidermal druses between the tips of the crystal were taken. The number of epidermal cells, stomata, and subepidermal druses per field was determined; those cells or druses which were in the border of the field were not considered in case that more than half of structure was out.

In transverse sections of the cladode, the tissues and the internal structure were analyzed. Thereby, quantitative features, such as thickness of external periclinal epidermal cell walls plus cuticle, hypodermis width and diameter of druses located in the cortex and pith were measured. All measurements were expressed in micrometer $(\mu \mathrm{m})$. The average dimensions (e. g. cells, stomata, and druses) were established on the basis of more than 50 measurements per sample.

Histochemical localization of cell components was performed for starch with iodine-potassium iodide (IKI) (Ruzin, 1999); mucilage was determined with a color reaction with blue brilliant of cresyl (1\%) (Zarlavsky, 2014), and to distinguish oxalate salts from carbonate we used acetic acid (5\%) test (Yasue, 1969). 


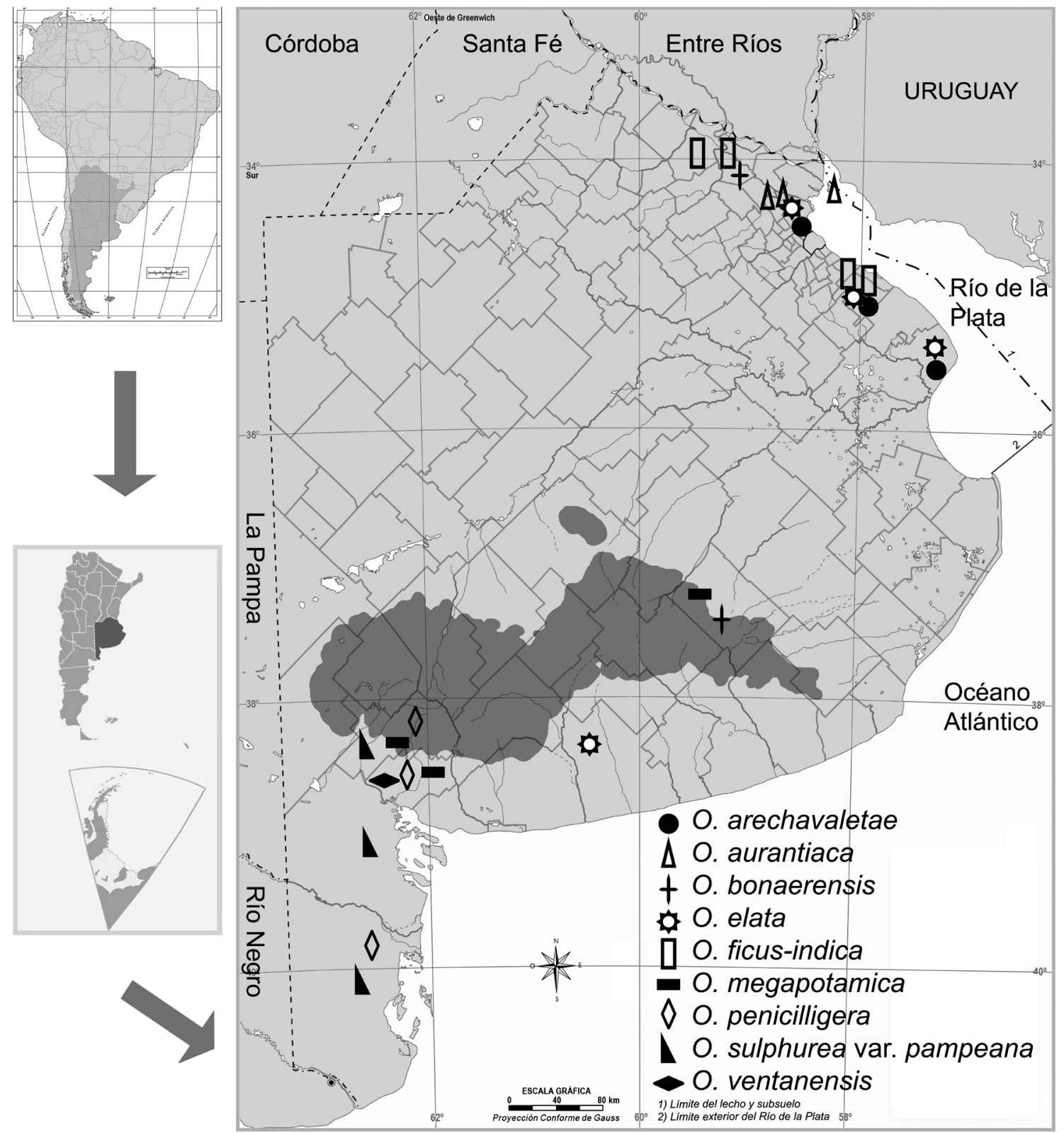

Fig. 1. Geographical points where the studied species of Opuntia were collected in the province of Buenos Aires (Argentina).

Microscopic studies were performed by means of a CETI T light microscope equipped with a camera lucida used to count cells, stomata and druses in surface view. The images were captured with a Moticam 1000 attached to the eyepiece of a microscope Gemalux XSZ-H, and Motic Image Plus 2.0 software. A Nikon E200 LED, equipped with digital camera and Micrometrics SE Premium software also was used.

Terminology is according to Metcalfe \& Chalk (1979), and for stomata type we used the classification of Ash et al. (1999). Scientific names are according to the Instituto de Botánica Darwinion, www.darwin.edu.ar. 


\section{Results}

Qualitative and quantitative characters are shown in Table 1 and Table 2. Quantitative values have been taken to whole numbers to facilitate reading and interpretation.

\section{Epidermal tissue}

Epidermal cells in surface view are polygonal in shape. We classified the anticlinal cell wall patterns as rectilinear to curved (e. g. $O$. arechavaletae, $O$. aurantiaca, O. megapotamica) (Fig. 2A); rectilinear to undulate, when some specimens exhibited linear anticlinal cell walls, and other one $\mathrm{U}$ undulate $(O$. penicilligera and $O$. sulphurea var. pampeana), and we found only $\mathrm{U}$ undulate in $O$. ficus-indica and $O$. ventanensis (Table 1; Fig. 2B). The epidermal cells size resulted less than $50 \mu \mathrm{m}$, with uniform thickness of the anticlinal cell walls; it ranged between 2-3 $\mu \mathrm{m}$ width (Table 1). The density of epidermal cells showed values lower to 1000 cells per unit of area (cells $/ \mathrm{mm}^{2}$ ), in $O$. aurantiaca, O. bonaerensis, and O. elata; whereas in the other species studied ranged from 1007 to 1696 cells $/ \mathrm{mm}^{2}$. There were not found important differences in the values of density between both cladode sides (Table 1).

In transverse section, the epidermis is smooth and uniseriate with the epidermal cells rectangular, covered by thin cuticle (2-3 $\mu \mathrm{m}$ width). The outer periclinal cell walls of the epidermis plus the cuticle ranged from 6 to $10 \mu \mathrm{m}$ width (Table 2, Fig. 2C, D). The widest values were found in $O$. penicilligera and $O$. sulphurea var. pampeana. Over the cuticle there is deposited a wide layer of waxes (epicuticular waxes) that is visible at optical microscope smooth and brightly, sometimes cracked and falling-out (Fig. 2D).

Stomatal apparatus is constituted by a stoma with its guard cells and some subsidiary cells. In surface view, the stomatal aperture between the two guard cells is covered by the outer stomatal ledge or rim of cuticle, which is prolonged to both poles, frequently adopting a T-piece shape (Fig. 3A). In transverse section, the stomata were found at the same level as the ordinary epidermal cells (Fig. 3B). The deep substomatal chamber go through the collenchymatic hypodermis as a channel, and it may be extending into the cortical parenchyma (e.g. $O$. arechavaletae, $O$. penicilligera, O. sulphurea var. pampeana) (Fig. 3B).
The sizes of stomata guard cells ranged from $36 \mu \mathrm{m}$ length $\times 21 \mu \mathrm{m}$ width in $O$. penicilligera to $57 \mu \mathrm{m}$ length $\times 31 \mu \mathrm{m}$ width in $O$. bonaerensis (Table 1). The stomata density per unit of area presented low values of 21,27 , and 34 stomata/ $\mathrm{mm}^{2}$. The lowest density was found in $O$. elata and the highest in $O$. arechavaletae, O. megapotamica, $O$. penicilligera, and $O$. sulphurea var. pampeana. Coincidently, these species showed the smallest epidermal cells (Table 1).

The stomata types were variable and frequently, there was more than one type of stoma in the same epidermis (Table 1). We found the amphibrachyparacytic stomata type with two subsidiary cells flanking the sides of the guard cells but no completely enclosing them (= brachy) and surrounded by a ring of curved cells (e. g. O. elata), or when there are four cells flanking the sides of guard cells with or without a ring of curved cells surrounding them (e. g. O. aurantiaca; O. ficusindica). Other type was amphibrachyparatetracytic with four subsidiary cells, disposed: two short cell lateral and parallel to the guard cells, and two wide polar subsidiary cells, and is surrounded by a ring of small curved cells (e. g. O. megapotamica). The brachyparahexacytic type has six subsidiary cells disposed as follows: four short cells lateral to the guard cells (two on each side), and two wide polar cells (e. g. O. ventanensis, Fig. 3C). It is amphibrachyparahexacytic when is surrounded by a ring of small and curved cells (e. g. O. sulphurea var. pampeana, Fig. 3D).

\section{Cortical tissues}

Hypodermis is located under the epidermis with 4-7 layers, the one under the epidermis has distinctive druses (Table 2; Figs. 2C, D; 3B, F). The hypodermis cells have primary cellulosic walls with irregular thickening of 13-32 $\mu \mathrm{m}$ width, and establish intercellular communication by primary pitted areas (Fig. 3E). This tissue is only interrupted by the stomatal chambers (Fig. 3B, E), and in transverse section, this hypodermis showed a thickness that ranged from $87 \mu \mathrm{m}$ to $164 \mu \mathrm{m}$ (Table 2). The druses diameter ranged from $27 \mu \mathrm{m}(O$. ventanensis) to $45 \mu \mathrm{m}$ (O. megapotamica) (Table 2 ). The density of druses in surface view, ranged from 138 to 814 druses $/ \mathrm{mm}^{2}$. High values (469-814) were present in $O$. ficus-indica, O. penicilligera, $O$. sulphurea var. pampeana, and O. ventanensis. 
Table 1. Epidermal features in surface view of the cladode of Opuntia (Cactaceae).

\begin{tabular}{|c|c|c|c|c|c|c|c|}
\hline \multirow[b]{2}{*}{ Taxa } & \multicolumn{4}{|c|}{ Epidermal Cells } & \multicolumn{3}{|c|}{ Stomata } \\
\hline & \multicolumn{2}{|c|}{$\begin{array}{l}\text { Anticlinal cell } \\
\text { walls patterns } \\
\text { width }(\mu \mathrm{m})\end{array}$} & $\begin{array}{l}\text { Size } \\
(\mu \mathrm{m})\end{array}$ & $\begin{array}{l}\text { Density } \\
\text { (c/mm2) }\end{array}$ & Type & $\begin{array}{l}\text { Size } \\
(\mu \mathrm{m})\end{array}$ & $\begin{array}{l}\text { Density } \\
\text { (s/mm2) }\end{array}$ \\
\hline O. arechavaletae & $\begin{array}{l}\text { rectilinear to } \\
\text { curved }\end{array}$ & 2 & $29 \times 22$ & $1041-1200$ & $\begin{array}{l}\text { amphybrachyparacytic } \\
\text { brachyparahexacytic }\end{array}$ & $46 \times 35$ & $34-34$ \\
\hline O. aurantiaca & $\begin{array}{l}\text { rectilinear to } \\
\text { curved }\end{array}$ & 3 & $35 \times 22$ & $793-917$ & $\begin{array}{c}\text { amphybrachyparacytic } \\
\text { amphybrachyparahexacytic } \\
\text { brachyparahexacytic }\end{array}$ & $38 \times 21$ & $27-27$ \\
\hline O. bonaerensis & $\begin{array}{l}\text { rectilinear to } \\
\text { curved }\end{array}$ & 3 & $44 \times 28$ & $869-890$ & $\begin{array}{c}\text { amphybrachyparacytic } \\
\text { amphybrachyparahexacytic } \\
\text { brachyparahexacytic }\end{array}$ & $57 \times 31$ & $27-27$ \\
\hline O. elata & $\begin{array}{l}\text { rectilinear to } \\
\text { curved }\end{array}$ & 3 & $38 \times 29$ & $800-972$ & $\begin{array}{c}\text { amphybrachyparacytic } \\
\text { amphybrachyparahexacytic } \\
\text { brachyparahexacytic }\end{array}$ & $57 \times 26$ & $21-21$ \\
\hline O. ficus-indica & U undulate & 3 & $49 \times 35$ & $1207-1276$ & $\begin{array}{c}\text { amphybrachyparacytic } \\
\text { amphybrachyparahexacytic }\end{array}$ & $45 \times 27$ & $21-27$ \\
\hline O. megapotamica & $\begin{array}{l}\text { rectilinear to } \\
\text { curved }\end{array}$ & 3 & $27 \times 17$ & $1359-1696$ & $\begin{array}{c}\text { amphybrachyparacytic } \\
\text { amphybrachyparatetracytic } \\
\text { amphybrachyparahexacytic }\end{array}$ & $48 \times 27$ & $27-34$ \\
\hline O. penicilligera & $\begin{array}{l}\text { rectilinear to } \\
U \text { undulate }\end{array}$ & 3 & $26 \times 19$ & $1524-1696$ & amphybrachyparahexacytic & $36 \times 21$ & $34-34$ \\
\hline $\begin{array}{l}\text { O. sulphurea var. } \\
\text { pampeana }\end{array}$ & $\begin{array}{l}\text { rectilinear to } \\
\text { U undulate }\end{array}$ & 3 & $31 \times 21$ & $1593-1696$ & amphybrachyparahexacytic & $46 \times 28$ & $27-34$ \\
\hline O. ventanensis & U undulate & 3 & $44 \times 24$ & $1007-1027$ & brachyparahexacytic & $42 \times 24$ & $27-27$ \\
\hline
\end{tabular}

Ref.: c: cells; s: stomata.

The cortical parenchyma is formed by the outermost photosynthetic cortical cells, and the innermost storage cortical cells, immediately adjacent to the stele. The photosynthetic chlorenchyma tissue represents $50-70 \%$ of the cladode cortex in all studied species. In surface view, it is formed by rounded cells leaving small intercellular spaces (Fig. 4A, C), and in lateral view, rectangular to quadrangular cell outlines, disposed with its major axis perpendicular to the surface (Fig. 4B, D-F). This parenchyma has straight thin primary cell walls, but sometimes they appear undulate (Fig. 4A, B, E). However, these cells showed thicker walls with different degree of cellulose thickening in O. penicilligera, O. sulphurea var. pampeana, and $O$. ventanensis (Fig. $4 \mathrm{C}, \mathrm{D}, \mathrm{F}$ ). The innermost cortical parenchyma represents $30-50 \%$ of the cortex. It is separated from the pith by a ring of vascular tissue. Both, internal parenchyma cortex and pith have isodiametric cells with thin primary cell walls, leaving small intercellular spaces. They are water-storage parenchyma (hydrenchyma), and in relation with that function they have numerous, large and globose mucilage cells (Fig. 4D). In the innermost cortical parenchyma and adjacent to the phloem of major vascular bundles may be found a reservoir (duct) of mucilage $(O$. bonaerensis, $O$. megapotamica, O. penicilligera, and O. sulphurea var. pampeana). Starch was identified as the principal reserve compound, and different crystal shapes of calcium oxalate were also found in the cortex and pith (Fig. 4F, f). In cross sections we measured the stellate druses with acute sharp points (Fig. 4F). The diameter of these druses ranged from 76 to $126 \mu \mathrm{m}$ (Table 2). They were conspicuously larger than in comparison to those of subepidermal layer. 
Table 2. Histological traits in transection of the cladode of Opuntia (Cactaceae).

\begin{tabular}{|c|c|c|c|c|c|c|c|c|c|}
\hline \multirow[b]{2}{*}{ Taxa } & \multirow{2}{*}{$\begin{array}{c}\text { Epidermis } \\
+ \\
\text { Cuticle } \\
\text { width } \\
(\mu \mathrm{m})\end{array}$} & \multirow{2}{*}{$\begin{array}{l}\text { Subepidermal } \\
\text { druses } \\
\text { size } \\
(\mu \mathrm{m})\end{array}$} & \multicolumn{3}{|c|}{ Hypodermis } & \multirow{2}{*}{$\begin{array}{l}\text { Parenchyma } \\
\text { druses } \\
\text { size } \\
(\mu \mathrm{m})\end{array}$} & \multicolumn{3}{|c|}{ Vascular bundles } \\
\hline & & & $\begin{array}{l}\text { Density } \\
\text { (d/mm2) }\end{array}$ & $\begin{array}{c}\text { Number } \\
\text { of } \\
\text { layers }\end{array}$ & $\begin{array}{l}\text { Width } \\
(\mu \mathrm{m})\end{array}$ & & $\begin{array}{l}\text { Duct } \\
\text { adjacent } \\
\text { to the } \\
\text { phloem }\end{array}$ & Fibres & $\begin{array}{c}\text { Wide- } \\
\text { band } \\
\text { tracheids }\end{array}$ \\
\hline O. arechavaletae & 7 & 35 & $214-214$ & 5 to 7 & 91 & 100 & a & a & $a / p$ \\
\hline O. aurantiaca & 7 & 32 & $365-386$ & 4 to 5 & 87 & 77 & a & $\mathrm{p}$ & a \\
\hline O. bonaerensis & 6 & 41 & $193-193$ & 4 to 5 & 111 & 76 & $\mathrm{p}$ & $\mathrm{p}$ & a \\
\hline O. elata & 7 & 39 & $138-172$ & 4 to 5 & 95 & 83 & a & $a / p$ & $a / p$ \\
\hline O. ficus-indica & 7 & 38 & $552-565$ & 4 to 6 & 145 & 84 & a & $a / p$ & $\mathrm{a} / \mathrm{pm}$ \\
\hline O. megapotamica & 7 & 45 & $262-276$ & 5 to 7 & 164 & 76 & $\mathrm{p}$ & $\mathrm{p}$ & $\mathrm{pm}$ \\
\hline O. penicilligera & 8 & 33 & $779-814$ & 4 to 6 & 134 & 86 & $p$ & $\mathrm{p}$ & $\mathrm{pm}$ \\
\hline $\begin{array}{l}\text { O. sulphurea var. } \\
\text { pampeana }\end{array}$ & 10 & 34 & $690-745$ & 5 to 7 & 111 & 126 & $\mathrm{p}$ & a & $\mathrm{pm}$ \\
\hline O. ventanensis & 7 & 27 & $469-490$ & 5 to 7 & 104 & 104 & a & a & pm \\
\hline
\end{tabular}

Ref.: (a) absence; (p) presence; $(\mathrm{pm})$ presence of a mass of wide-band tracheids.

\section{Vascular tissue}

The studied species of Opuntia have different size of collateral vascular bundles ordered in eustele. The small ones are formed by phloem, and opposite to the phloem on the inner side is the xylem, with two to ten narrow vessels, with helical secondary walls, and disposed in a row, intercalate with parenchyma of the xylem. The vascular bundle is surrounded by parenchyma differentiated from the medullary rays, it appears as a parenchymatic sheath (Fig. 5A). In the vascular bundle of medial size the xylem has a greater number of vessels with helical or pseudohelical secondary cell walls, and simple perforation plates (Fig. 5B). In general, the xylem of the studied Opuntia species (e. g. $O$. arechavaletae) exhibited a relatively large number of narrow vessels with helical secondary walls and parenchyma. In the xylem of $O$. aurantiaca, O. bonaerensis, O. elata (some specimens), O. ficusindica, $O$. megapotamica, and $O$. penicilligera were found clusters of libriform fibres (Table 2; Fig. 5C). In the xylem of $O$. ficus-indica; O. megapotamica, $O$. penicilligera, O. sulphurea var. pampeana, and $O$. ventanensis the wide-band tracheids (WBTs) were found. These especial cell types are located between the vessels, and around the vessels of the xylem (Figs. 5D; 6A, B). The wide-band tracheids are closed as a tracheid, and frequently also they adopt a spindle form in longitudinal view (Fig. 6A). These cells showed primary cellulosic walls, and internally two to four or six lignified annular rings or discs of secondary wall (Fig. 6A). We named ring when the secondary wall leave enough lumen, and disc when the lumen is very reduced nearly a point, after the secondary thickenings project deeply into de lumen (Fig. 6B). We found in O. megapotamica, O. penicilligera, O. sulphurea var. pampeana, and $O$. ventanensis, the WBTs forming great masses in the xylem, and extending into the pith, and they also appear connecting two to more vascular bundles (Fig. 6C, D).

\section{Discussion}

Epidermal cells in surface view showed variability of anticlinal cell wall patterns. It appears as a Cactaceae features, because it was previously mentioned by Loza-Cornejo \& Terrazas (2003) for the Cactoideae of North America. The waviness of epidermal cell walls had been 


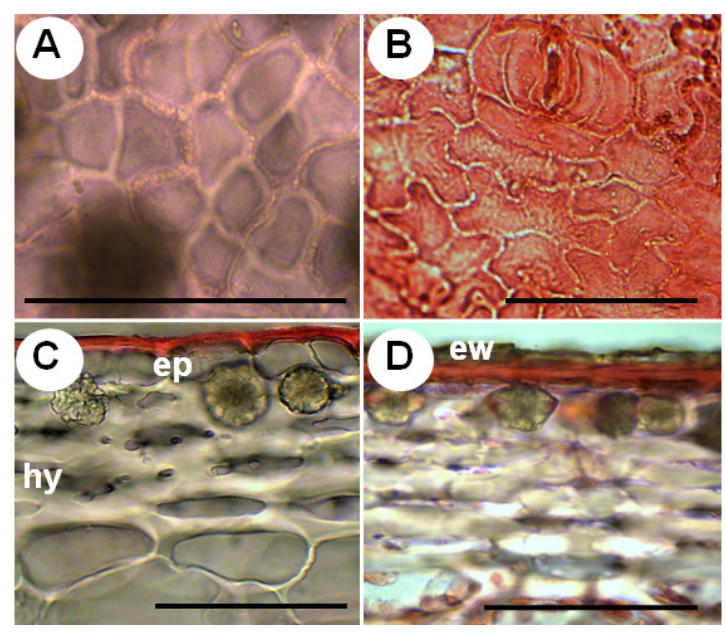

Fig. 2. Epidermis in surface view: A-B. A, rectilinear to curved anticlinal epidermal cell walls pattern (O. megapotamica). B, undulate anticlinal epidermal cell walls pattern (O. ventanensis). Epidermis and hypodermis in transection of the cladode: C-D. C, outer periclinal epidermal cell walls plus cuticle; hypodermis showing the crystal layer with druses (O. elata). D, epicuticular waxes over the cuticle (O. ventanensis). Ref.: ep, epidermis; ew, epicuticular waxes; hy, hypodermis. Scale bars $=100 \mu \mathrm{m}$.

associated with environmental factors, such as latitude, altitude, and combined temperature and precipitation (Stace, 1965; Metcalfe \& Chalk, 1979). In fact, it is not clear in the present research, but we are working with another organ, and we can hypothesize this characteristic may be also influenced by stem grows, flattened and rounded. In a drought-stressed condition the plants show substantial wilting, and the cell walls become to bend if they do not have enough rigidity (Schulze et al., 2005). Therefore, we think that those species with small epidermal cells, more or less rectilinear walls, and thicker periclinal cell walls plus cuticle and epicuticular waxes (e. g. O. penicilligera and O. sulphurea var. pampeana) are more resistant to suffer cytorrhysis. The superficial stomata position agrees with data reported by Pereira de Arruda \& Melo-de-Pina (2015) in their Opuntioideae research, and it is supposed the deep stomatal chamber going through thickened multiseriate hypodermis does slow down water loss. The
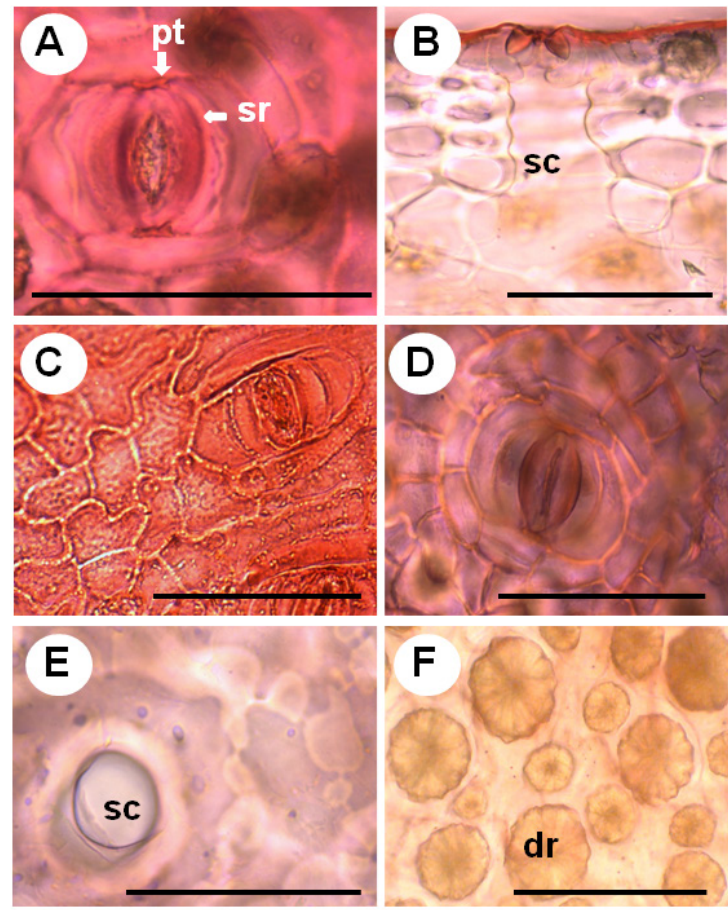

Fig. 3. Stomata and hypodermis. A, stomata in surface view, showing the outer stomatal rim of cuticle and polar thickening (O. aurantiaca). B, transection of stomata showing guard cells, subsidiaries, and substomatal chamber (O. arechavaletae). C, brachyparahexacytic stomata type (O. ventanensis). $D$, amphybrachyparahexacytic $(O$. sulphurea var. pampeana). E, hypodermis in surface view, showing primary pitted areas, and a substomatal chamber as a channel through the hypodermis (O. ventanensis). $F$, rounded druses of the subepidermal crystal layer in surface view (O. ficus-indica). Ref.: dr, druses; sc, substomatal chamber; sr, stomatal rim of cuticle; pt, polar thickening. Scale bars $=100 \mu \mathrm{m}$.

stomata type was found with a variable number of subsidiary cells as was noted by Eggli (1984) who named stoma "opuntioid". These types accord well with paracytic, parallelocytic, tetracytic, and hexacytic combined with cyclocytic of Metcalfe \& Chalk (1979). Results in general, agree with the stomata types indicated for the family and subfamily by previous authors (Eggli, 1984; Gibson \& Nobel, 1986; Arruda et al., 2005; Calvente et al., 2008; Faigon et al., 2010; Pereira de Arruda \& Melo-de-Pinna, 2015). We found hexacytic as the 


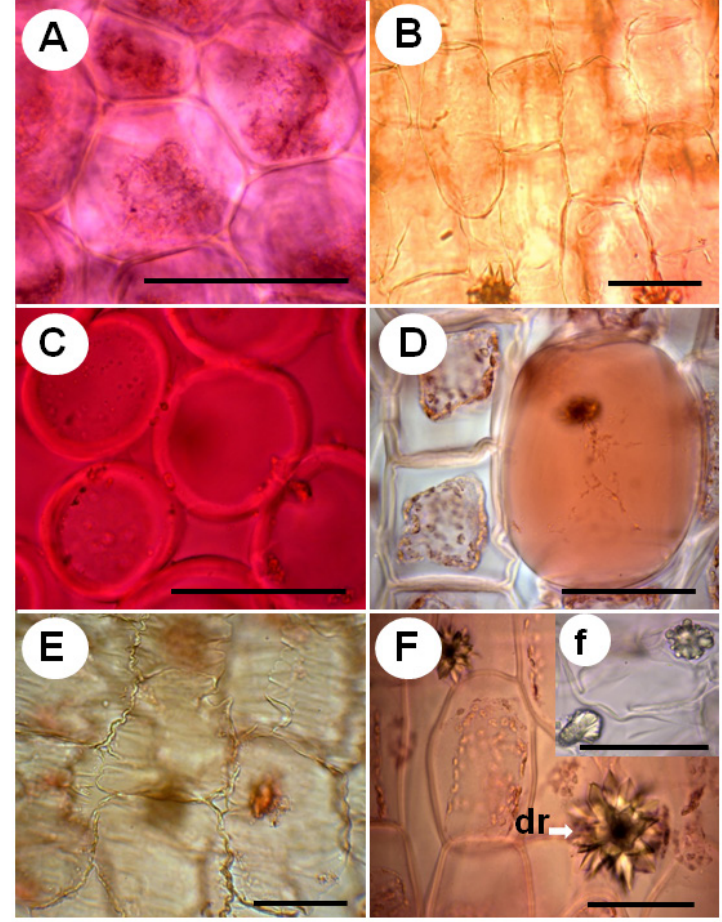

Fig. 4. The chlorenchyma. A, in surface view; $B$, in lateral view; $\mathbf{A}, \mathbf{B}$, both with thin cell walls $(O$. arechavaletae). C, in surface view; $\mathbf{D}$, in lateral view, and one mucilage cell; C, D, both with thicker cell walls (O. penicilligera). E, in lateral view with thin and sinuous cell walls (O. elata). $\mathbf{F}$, different calcium oxalate crystal types in the parenchyma tissue $(O$. penicilligera). Ref.: dr, druses; $\mathbf{f}$, different crystal types. Scale bars $=100 \mu \mathrm{m}$.

most frequent type of stoma (brachyparahexacytic and amphybrachyparahexacytic). The hypodermis tissue was found 4-7 layered in the studied Opuntia species. Pereira de Arruda \& Melo-de-Pinna (2015) found the number of layers of hypodermis variable (2-10) in different species of Opuntia. Whilst we doing this work observed that cladodes in specimens of $O$. arechavaletae growing under trees, in shadow conditions, had a hypodermis 2-3 layered with reduced thickening in the cell walls. It would be interesting to consider in future studies the effect of environmental factors on this tissue. In the cortex, the thickening in chlorenchyma cell walls exhibited by $O$. penicilligera, $O$. sulphurea var. pampeana, and $O$. ventanensis could be an adaptation to xerophytic environment. The thicker
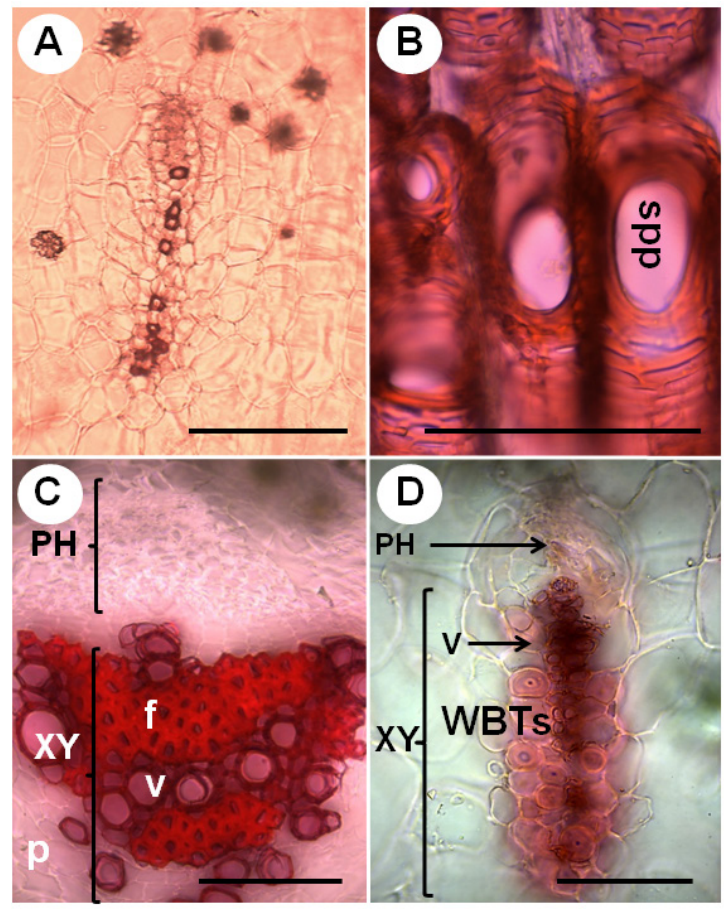

Fig. 5. Vascular bundles. A, small vascular bundle (O. elata). B, vessels with simple perforation plates (O. elata). C, vascular bundle showing phloem and xylem with vessels, fibres and parenchyma (O. aurantiaca). D, small vascular bundle showing phloem, xylem with vessels and wide-band tracheids (O. ventanensis). Ref.: f, fibres; $\mathbf{p}$, parenchyma; $\mathbf{P H}$, phloem; spp, simple perforation plates; v, vessels; WBTs, wide-band tracheids; XY, xylem. Scale bars $=100 \mu \mathrm{m}$.

cell walls are more rigid doing more resistant cells (Mauseth, 1995). We can speculate that similar to what happens with epidermal cells, here the thickening of the walls support and prevent cellular collapse. The internal storage water cells are flexible, they are adapted to absorb water during wet conditions and then supply water to the chlorenchyma during drought stress as were previously described and illustrated by Mauseth (1995). All studied species of Opuntia exhibited a variety of crystalline forms. We found the whewellite type (Monje \& Baran, 2002), and others types of crystals. We feel that is another interesting point to continuous exploring in these species of Opuntia. The function of oxalate crystals 


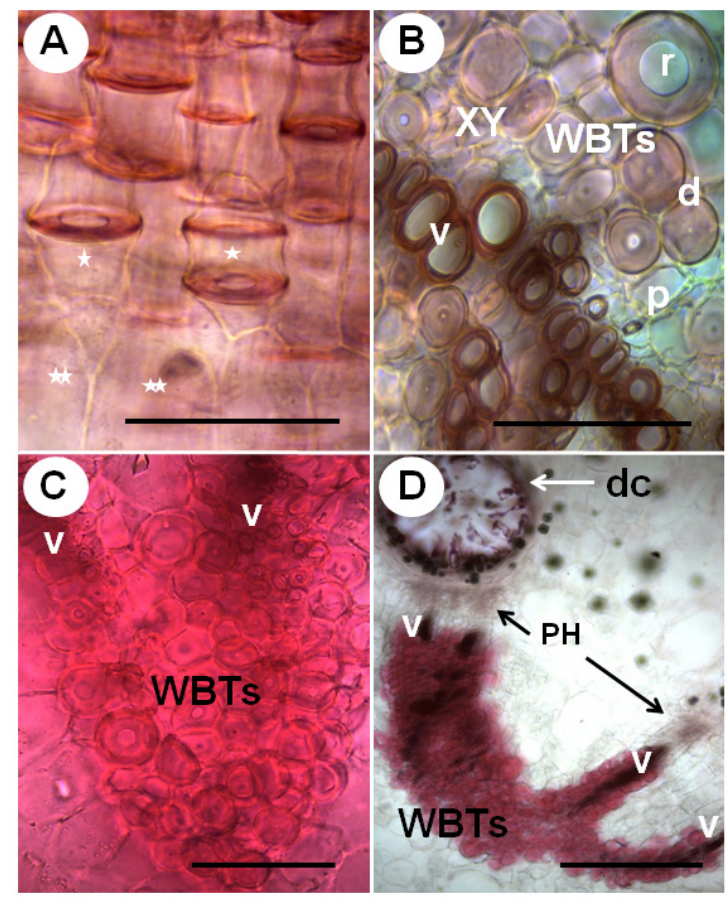

Fig. 6. Vascular tissue. A, longitudinal view of wide-band tracheids (WBTs) with spindle shapes (indicated by one asterisk). It may be seen some parenchyma cells (indicated by two asterisk) ( $O$. sulphurea var. pampeana). B, xylem showing vessels, parenchyma, and WBTs, where may be distinguished between annular ring and disc thickenings ( $O$. ventanensis). C, WBTs connecting two vascular bundles (O. megapotamica). D, one large vascular bundle with a duct adjacent to the phloem, surrounded by druses, and a mass of WBTs connecting this with other two vascular bundles forming a bunch (O. megapotamica). Ref.: d, disc; dc, duct; p, parenchyma; PH, phloem; r, ring; v, vessels; WBTs, wide-band tracheids; $\mathbf{X Y}$, xylem. Scale bars $=100 \mu \mathrm{m}$.

storage in plants still persists unresolved. Monje \& Baran (2002) suggested that precipitation of calcium oxalate in the tissues of succulent plants may be related with preserving water. This could explain the high concentration of oxalate crystals found in specimens studies of $O$. penicilligera and O. sulphurea var. pampeana collected in semiarid region. More recently investigations (Hartl et al., 2007) also referred that the subfamily Opuntioideae has predominantly monohydrated crystals. Tovar-
Puente et al. (2007) analyzed the possibility to use crystals density as a tool to distinguish cultivars of the genera Opuntia and Nopalea and they had positive results among cultivars studied. However, they also recognize the convenience to continuous working increasing the number of samples from different edaphic conditions. In the xylem the WBTs would be involved in water storage and secondary in transference of water since the cell walls are very thin to be able to fulfill these functions, as well as to adapt to the processes of hydration and dehydration without suffering collapse they form the secondary thickenings. It is in agreement with the function concept referred by Boke (1944) and Gibson \& Nobel (1986). Mauseth (1999) indicated that these cells constitute a strategy to water storage as well as minimize embolism damage. On the presence of these special cells we found some variations, for example in O. megapotamica, which is a species with ample area of distribution, the specimen collected in Cerro de la Ventana (a cold, dry area with stony soil) had a mass of wide-band tracheids, whereas the specimen collected in Villa María (a warm, rainy area) had no wide-band tracheids. Further studies are necessary to establish whether there is a real significant correlation between climate and wide-band tracheids. On the basis of the quantity of these special cells found in O. penicilligera, $O$. sulphurea var. pampeana, and $O$. ventanensis, we hypothesize that the development of the wide-band tracheids is favoured by extreme xeric conditions, perhaps in presence of physiological drought, when the plants are growing on the driest soils or saline soils.

\section{Conclusions}

It is the first stem anatomy description and illustration of nine species of Opuntia, from Buenos Aires province. The depth of the study allowed us to know superficial and internally features of this group of species. Some characters (e. g. presence of fibres and ducts) may be a useful tool for plant identification. However, many open questions remain to be investigated such as the correlation of the environment factors with hypodermis, calcium oxalate crystals, and wideband tracheids. 


\section{ACKNOWLEDgements}

We acknowledge L. Katinas and G. Giudice, for reviewing the early version of the manuscript. We also thank to J. D. Mauseth for his meticulous reading and criticism, providing suggestions that contributing to improve the research. We extend this knowledge to the anonymous reviewers, and editors. We are also grateful to A. Bartoli, M. A. Long, G. Bernardello, F. Font, M. Hernández who contributed with bibliography and fresh material, and to M. A. Migoya the drawing in Fig. 1. We gratefully acknowledge assistance to curators of herbaria BA, BAA, LP, SI who provided material for examination.

\section{BibliogRAPHY}

ASH, A., B. ELLIS, L. J. HICKEY, K. JOHNSON, P. WILF \& S. WING. 1999. Manual of leaf architecture - morphological description and categorization of dicotyledonous and net-veined monocotyledonous angiosperms by Leaf architecture working group. Smithsonian Institution. Washington, D. C.

ARRUDA, E., G. F. MELO-DE-PINNA \& M. ALVES. 2005. Anatomia dos órgãos vegetativos de Cactaceae da caatinga pernambucana. Rev. Bras. Bot. 28: 589601.

BOKE, N. H. 1944. Histogenesis of the leaf and areola in Opuntia cylindrica. Am. J. Bot. 31: 299-316.

CABRERA, A. L. \& H. A. FABRIS. 1965. Cactaceae. En: CABRERA, A. L. (ed.), Flora de la Provincia de Buenos Aires. Colecc. Ci. Inst. Nac. Tecnol. Agropecu. 4: 262-292.

CALVENTE A. M., R. H. P. ANDREATA \& R. C. VIEIRA. 2008. Stem anatomy of Rhipsalis (Cactaceae) and its relevance for taxonomy. Pl. Syst. Evol. 276: 1-7.

CONDE, L. F. 1975. Anatomical comparison of five species of Opuntia (Cactaceae). Ann. Mo. Bot. Gard. 62: 425-473.

EGGLI, U. 1984. Stomatal types of Cactaceae. Pl. Syst. Evol. 146: 197-214.

FAIGON, A., B. G. GALATI, S. ROSENFELDT \& R. KIESLING. 2010. Epidermal characters of Pterocactus (Opuntioideae, Cactaceae). Haseltonia 16: 57-66.

FONT, F. 2014. A revision of Opuntia series Armatae K. Schum (Opuntia ser. Elatae Britton \& Rose, Cactaceae-Opuntioideae). In: HUNT, D. (ed.). Further studies in the Opuntioideae (Cactaceae), pp. 51-94.

GIBSON, C. G. \& P. S. NOBEL. 1986. The Cactus Primer. Cambridge, Mass. Harvard University Press, Cambridge, Massachusetts.
HARTL, W. P., H. KLAPPER, B. BARBIER, H. J. ENSIKAT, R. DRONSKOWSKI, P. MÜLLER, G. OSTENDORP, A. TYE, R. BAUER \& W. BARTHLOTT. 2007. Diversity of calcium oxalate crystals in Cactaceae. Can. J. Bot. 85: 501-517.

INSTITUTO DE BOTÁNICA DARWINION - IBODA - CONICET. www.darwin.edu.ar/ [Accessed: 2017/07/06].

JOHANSEN, D. A. 1940. Plant microtechnique. Mc Graw Hill Book Company, Inc. New York.

KIESLING, R. 1975. Géneros de Cactaceae de Argentina. Bol. Soc. Argent. Bot. 16: 197-227.

KIESLING, R. 1988. Cactaceae. En: CORREA, M. M. (ed.), Flora Patagónica, Dicotiledóneas dialipétalas (Oxalidaceae a Cornaceae). Colecc. Ci. Inst. Nac. Tecnol. Agropecu. 8: 218-243.

KIESLING, R. 1999. Cactaceae. En:ZULOAGA, F. O. \& O. MORRONE (eds.), Catálogo de las Plantas Vasculares de la República Argentina. II. Dicotyledoneae. Monogr. Syst. Bot., Mo. Bot. Gard. 74: 423-489.

KIESLING, R. 2003. Cactaceae. Flora de San Juan, República Argentina. Dicotiledóneas Dialipétalas (Oxalidáceas a Umbeliferas). Estudio Sigma 2: 161163.

KIESLING, R. 2005. Cactaceae. En: BACIGALUPO, N. M. (ed.), Flora Ilustrada de Entre Ríos. Colecc. Ci. Inst. Nac. Tecnol. Agropecu. 6: 401-444.

LAS PEÑAS, M. L., L. OAKLEY, N. C. MORENO \& G. BERNARDELLO. 2017. Taxonomic and cytogenetic studies in Opuntia ser. Armatae (Cactaceae). Botany 95: 101-120.

LONG, M. A. 2012. Opuntia ventanensis (Cactaceae), a new species from the province of Buenos Aires, Argentina. Haseltonia 18: 79-84.

LOZA-CORNEJO, S. \& T. TERRAZAS. 2003. Epidermal and hypodermal characteristics in North American Cactoideae (Cactaceae). J. Plant Res. 116: 27-35.

MAUSETH, J. D. 1995. Collapsible water-storage cells in cacti. Bull. Torrey Bot. Club 122: 145-151.

MAUSETH, J. D. 1999. Anatomical adaptations to xeric conditions in Maihuenia (Cactaceae), a relictual, leafbearing cactus. J. Plant Res. 112: 307-315.

MAUSETH, J. D. 2005. Anatomical features, other than wood, in subfamily Opuntioideae (Cactaceae). Haseltonia 11: 113-125.

MAUSETH, J. D. 2006. Wood in the cactus subfamily Opuntioideae has extremely diverse structure. Bradleya 24: 93-106.

MAUSETH, J. D. \& B. J. PLEMONS-RODRIGUEZ. 1998. Evolution of extreme xeromorphic characters in wood: A study of nine evolutionary lines in Cactaceae. Am. J. Bot. 85: 209-218.

MELO-DE-PINNA, G. F., E. ARRUDA \& D. D. ABREU. 2006. Wide-band tracheids in Brazilian cacti. Bradleya 24: 53-60. 
METCALFE, C. R. \& L. CHALK. 1979. Anatomy of the Dicotyledons. v. 1. Clarendon Press, Oxford.

MONJE, P. V. \& E. J. BARAN. 2002. Characterization of calcium oxalate generated as biominerals in Cacti. Plant Physiol. 128: 707-713.

NATTERO, J. \& R. MALERBA. 2011. Biología de especies australes: Opuntia quimilo K. Schum. Kurtziana 36: 79-87.

ORTEGA-BAES, P., S. SÜHRING, J. SAJAMA, E. SOTOLA, M. ALONSO-PEDANO, S. BRAVO \& H. GODÍNEZ-ALVAREZ. 2010. Diversity and conservation in the cactus family. In: RAMAWAT, K. G. (ed.), Desert Plants. Berlin, Heidelberg. Springer.

PEREIRA de ARRUDA, E. C. \& G. F. de MELO-dePINNA. 2015. Caracteres anatômicos do segmento caulinar em espécies da subfamilia Opuntioideae (Cactaceae). Hoehnea 42: 195-205.

REALINI, M. F., G. E. GONZÁLEZ, F. FONT, P. I. PICCA, L. POGGIO \& A. M. GOTTLIEB. 2014. Phylogenetic relationships in Opuntia (Cactaceae, Opuntioideae) from southern South America. Pl. Syst. Evol. 301: 1123-1134.

RUZIN, S. E. 1999. Plant microtechnique and microscopy. Oxford, Oxford University Press.

SCHULZE, E. D., E. BECK \& K. MÜLLERHOHENSTEIN. 2005. Plant Ecology. Berlin, Heiderlberg. Springer.

STACE, C. A. 1965. Cuticular studies as an aid to plant anatomy. Bull. Br. Mus. (Nat. Hist.) Bot. 4: 1-78.
THIERS, B. [continuously updated]. Index Herbariorum: A global directory of public herbaria and associated staff. New York Botanical Garden's Virtual Herbarium. Available from: http://sweetgum.nybg. org/ih/ [Accessed: 2017/07/06].

TOVAR-PUENTE, A., M. PANDO-MORENO, H. GONZÁLEZ-RODRÍGUEZ, L. SCOTTMORALES \& S. MÉNDEZ-GALLEGOS. 2007. Densidad de cristales de oxalato de calcio en quince cultivares de nopal. J. Prof. Assoc. Cactus Journal: 91-98.

VERGEZ MANGHI, J., V. PÉREZ CUADRA, V. CAMBI \& A. LONG. 2015. Anatomía caulinar de tres especies de Opuntia de Argentina central. Bol. Soc. Argent. Bot. 50 (Suplemento): 74.

YASUE, T. 1969. Histochemical identification of calcium oxalate. Acta Histochem. Cytochem. 2: 83-95.

ZARLAVSKY, G. E. 2014. Histología vegetal. Técnicas simples y complejas. Sociedad Argentina de Botánica, Buenos Aires.

ZULOAGA, F. O., O. MORRONE \& M. J. BELGRANO. 1999. Análisis de la biodiversidad en plantas vasculares de la Argentina. Kurtziana 27: 17-167.

ZULOAGA, F. O., O. MORRONE \& M. J. BELGRANO (eds.). 2008. Catálogo de las Plantas Vasculares del Cono Sur. Monogr. Syst. Bot., Mo. Bot. Gard. 107.

Recibido el 1 de marzo de 2018, aceptado el 20 de mayo de 2018. Editora: Ana María Gonzalez. 


\section{Bol. Soc. Argent. Bot. 53 (3) 2018}

Appendix: Species of Opuntia from Argentina, Buenos Aires province, with representative specimens studied. References: \#: cultivated, *: in preservation liquid, LAMCE.

O. arechavaletae Speg. Prov. Buenos Aires: Pdo. San Isidro, San Isidro, región de la costa, 15-XI-1956, Burkart 17911 (SI). Det. Kiesling 1999. Prov. Misiones: Dpto. Montecarlo, Puerto Piray, 25-I-1952, Castellanos 19411 (BA). Fresh material: Prov. Buenos Aires: Pdo. Punta del Indio, Punta Indio, X-2013, M. P. Hernández (\#, *). Pdo. La Plata, La Plata, Diag. 113 esq. 116, XII-2012, V. G. Perrotta (*).

O. aurantiaca Lindl. Prov. Buenos Aires: Pdo. La Plata, Isla Martín García, 25-XI-1983, Nuncia M. Tur et al., 1793 (LP); Pdo. Campana, Reserva Natural Otamendi, 25-XI-1962, Burkart 23905 (SI); Pdo. Escobar, Belén de Escobar, barrancas cerca del Golf club, IV-1986, Erb s. n. (SI 028496). Prov. Entre Ríos: Dpto. Gualeguaychú, Gualeyán, Arroyo al norte de Irazusta, 18-IV-1965, Burkart 25761 (SI). Det. Kiesling en 1995.

O. bonaerensis Speg. Prov. Buenos Aires: Pdo. Zárate, Estación Las Palmas, 13/XII/1951, Boelcke s. n., Det. Leuenberger 5149 (SI); Pdo. Tandil, al oeste del Cerro San Luis, Tandilia, 1996, B. Leuenberger 4516 (SI). Fresh material: Prov. Buenos Aires: Pdo.Tandil, Monte Calvario, 12-XI-2013, M. P. Hernández. (Identified as O. paraguayensis K. Schum.); Pdo. La Plata, Villa Elisa, XI-2013, V. G. Perrotta and M. P. Hernández (*).

O. elata Salm-Dyck. Prov. Buenos Aires: Pdo. La Plata, Manuel B. Gonnet, 3-XII-1942, Cabrera 7621 (SI). Det. F. Font, 2009 como O. elata var. obovata E. Whalter; Dpto. Tres Arroyos, Hueso Clavado, hacia ruta 228, 6-XII-1987, Gazzaniga s. n. Det. Villamil 5603 (SI). Pdo. Escobar, Belén de Escobar, barrancas cerca del Golf club, IV-1986, Erb s. n. (SI 028495). Det. Oakley como Opuntia elata aff. elata. Prov. Corrientes: Dpto. San Cosme, a 4 km al este de Paso de la Patria, 22-II-1969, Krapovickas \& Cristóbal 14939 (LP). Det. F. Font como O. elata var. elata; Dpto. Capital, Ruta 12 y camino Santa Ana, en quebrachal, 18-XI-1973, Krapovickas \& Cristobal 23736 (LP). Det. F. Font, XI-2009, as O. elata var. elata; Dpto. San Martín, Carlos Pellegrini, 30-X-1971, Krapovickas et al. 20125 (LP). Det. F. Font, dic. 2009 as O. elata; Dpto. Ituzaingó, Isla Apipé Grande, Puerto San Antonio, 10-XII-1973, Krapovickas et al., 24104 (LP). Det. F. Font, XI-2009 as O. elata (Our obs.: may be O. elata SalmDyck var. cardiosperma (K. Schum.) R. Kiesling, because this specimen has large oblong cladodes and vascular bundles with fibres in the xylem). Prov. Entre Rios: Dpto. Colón, Parque Reserva Nacional "El Palmar", 8-XII-1976, Fernández Velazco s. n. (BA). Det. Leuenberger 2004, as O. cardiosperma K. Schum. Det. Oakley, 21-IV-2014 as O. elata var. elata. (Our obs.: may be O. elata var. cardiosperma, because this specimen has large oblong cladodes and vascular bundles with fibres in the xylem). Fresh material: Prov. Buenos Aires: Pdo. Punta del Indio, Punta Indio, X-2013, M. P. Hernández (\#, *).

O. ficus-indica (L.) Mill. Prov. Buenos Aires: Pdo. Baradero, Baradero. sobre la barranca, 19-XII-1937, Burkart 8500 (LP). Det. F. Font, XI-2009; Pdo. Zárate, Lima, sobre barranca del Paraná, 13-XI-1965, Cabrera 17241 (LP). Det. F. Font, XI-2009. Fresh material: Prov. Buenos Aires: Pdo. La Plata, La Plata, Facultad de Agronomía, 27-XII-2012, V. G. Perrotta \& M. P. Hernández (*); Pdo. Berazategui, Juan M. Gutiérrez, X-2017, V. G. Perrotta $(*)$.

O. megapotamica Arechav. Prov. Buenos Aires: Pdo. Tornquist, Sierra de la Ventana, XI-1941, Cabrera 7560 (LP); Proyecto Ventania 760, 26-XI-1979, Det. F. Font; Pdo. Bahía Blanca, G. Militar, 21-XII1909 (16416 BAA), Det. Leuenberger, 19-II-2008 as O. elata (Our obs.: vascular bundles are coincident with O. megapotamica). Prov. Córdoba: Dpto. General San Martín, Villa María, 12-X-1964, Cabrera \& Fabris 15934 (LP). Det. F. Font, XI-2009. Fresh material: Prov. Buenos Aires: Pdo. Tandil, Sierra de las Ánimas, 12-XI-2013, M. P. Hernández. Identified as O. vulgaris Mill. (*).

O. penicilligera Speg. Prov. Buenos Aires: Pdo. Tornquist, Sierra de la Ventana, Estancia Funke, 14-XI1943, Cabrera 8126 (LP); Pdo. Patagones, Carmen de Patagones, XI- 1972, Narosky \& Izurieta 1 (LP 007081). Det. Kiesling, V-1972. Fresh material: Prov. Buenos Aires: Pdo. Bahía Blanca. (\#, *). 
O. sulphurea Gillies ex Salm-Dyck var. pampeana (Speg.) Backeb. Prov. Buenos Aires: Pdo. Patagones, Carmen de Patagones, 5-XII-1918, Cabrera 4793 (SI). Det. Kiesling; Pdo. Tornquist, Sierra de la Ventana, cerro cerca del hotel Ymcapolis, 6-XII-1971, Burkart 28964 (SI); Pdo. Villarino, Salinas chicas, s. f., Fabris 5685 (LP); Pdo. Villarino, $60 \mathrm{~km}$ al oeste de Pedro Luro, XII-1964, Fabris 5636 (LP).

O. ventanensis A. Long. Prov. Buenos Aires: Pdo. Bahía Blanca, cultivada en el Jardín Botánico "Lucien Hauman", Facultad de Agronomía, Universidad Nacional de Buenos Aires, IX-2017 (\#, *). 
